\title{
Progesterone Function in Human Endometrium: Clinical Perspectives
}

\author{
Steven L. Young, M.D., Ph.D., ${ }^{1}$ and Bruce A. Lessey, M.D., Ph.D. ${ }^{2}$
}

Progesterone is essential for endometrial receptivity and successful establishment of pregnancy. Either an insufficient progesterone concentration or an insufficient response to progesterone, therefore can lead to infertility and pregnancy loss. Assessment of the role that either progesterone insufficiency or inadequate progesterone response plays in human reproductive failure has been difficult to assess because serum progesterone concentrations fluctuate markedly, limiting the ability to characterize sufficiency of progesterone, and there are no highly reliable markers of endometrial function available. Recent evidence demonstrates exquisite sensitivity of normal endometrium to very low levels of progesterone stimulation, suggesting that progesterone insufficiency should not be a common cause of reproductive failure. Further evidence suggests that women with endometriosis, and possibly polycystic ovarian syndrome, have an altered progesterone response, which may explain some of the clinical features of these disorders and supports the hypothesis that progesterone resistance underlies some cases of human reproductive failure.

KEYWORDS: Luteal phase defect, progesterone resistance, endometrium, embryo implantation, endometriosis

$\mathrm{P}_{\text {rogesterone }(\mathrm{P}) \text { is a sex steroid essential for }}$ pregnancy and lactation produced almost entirely by the ovarian corpus luteum (CL) and the placenta. Normal endometrial function requires both estrogen (E), which mediates cell growth and induction of progesterone receptors (PR), and $\mathrm{P}$, which counteracts $\mathrm{E}$ stimulation and downregulates the receptors for $\mathrm{E}$ and $\mathrm{P}$. The normal balance achieved by sequential actions of $\mathrm{E}$ and $\mathrm{P}$ is essential to the normal cyclic functions of human endometrium, and disruption of this balance is a significant factor in the pathogenesis and/or pathophysiology of many clinical problems, including endometriosis, infertility, abnormal bleeding, pregnancy loss, and cancer.
The mechanisms governing $\mathrm{P}$ action on endometrium are complex, involving at least two receptor subtypes (PR-A and PR-B), with distinct expression patterns and functional profiles as well as other putative $\mathrm{P}$ receptors, whose identity and function remain an active area of research. ${ }^{1}$ The effects of PR-A and PR-B are further modulated by differential expression and activation of coregulators such as SRC1-3. Furthermore, many of P's important effects on endometrium are indirect, via paracrine and autocrine factors.

Although mechanistically complex, $\mathrm{P}$ is essential for successful embryo implantation and pregnancy maintenance. Therefore, levels of circulating $\mathrm{P}$ below some undefined threshold or resistance of endometrium to
${ }^{1}$ Department of Obstetrics and Gynecology, Division of Reproductive Endocrinology and Infertility, University of North Carolina, Chapel Hill, North Carolina; ${ }^{2}$ Department of Obstetrics and Gynecology, Division of Reproductive Endocrinology and Infertility, University Medical Group, Greenville Hospital System, Greenville, South Carolina.

Address for correspondence and reprint requests: Steven L. Young, M.D., Ph.D., Department of Obstetrics \& Gynecology (CB\# 7570), 4005 Old Clinic Bldg, University of North Carolina at Chapel Hill,
Chapel Hill NC 27599-7570 (e-mail: youngs@med.unc.edu).

Progesterone Resistance and Endometrial Disease; Guest Editor, Serdar E. Bulun, M.D.

Semin Reprod Med 2010;28:5-16. Copyright (C) 2010 by Thieme Medical Publishers, Inc., 333 Seventh Avenue, New York, NY 10001, USA. Tel: $+1(212) 584-4662$.

DOI: http://dx.doi.org/10.1055/s-0029-1242988.

ISSN 1526-8004. 
otherwise adequate $\mathrm{P}$ will result in infertility or pregnancy loss. This concept of insufficiency of $\mathrm{P}$ action on endometrium comprises the pathophysiological concept of luteal phase deficiency. However, whether sufficiently low $\mathrm{P}$ or sufficiently resistant endometrium is encountered clinically remains to be demonstrated definitively. In this article, we focus on the role of sex steroids in endometrial function in women and review the evidence for $\mathrm{P}$ insufficiency versus $\mathrm{P}$ resistance, using clinical examples that illustrate the importance of appropriate $\mathrm{P}$ action.

\section{HISTORY}

The importance of sex steroids was first recorded by Aristotle in $350 \mathrm{BCE}$ when he reported the dramatic changes in the cockerel following removal of the gonads. Berthold ${ }^{2}$ transplanted testes into a capon and demonstrated comb growth. In the 1920s, Allen and Doisy demonstrated that follicular fluid from porcine ovaries was capable of inducing estrus in the female. ${ }^{3}$ Hisaw and colleagues showed how these extracts also inhibited ovulation ${ }^{4}$ and induced deciduomata formation. ${ }^{5}$ Allen and Corner performed classic studies on the requirement for CL extract on secretory transformation and pregnancy maintenance. ${ }^{6}$ These early studies identified what would later be known as estrogen and progesterone, and they illustrated their complex counterregulatory functions in reproduction.

The subsequent discovery of specific receptors for $\mathrm{E}$ and $\mathrm{P}$ allowed researchers to define tissue sensitivity in molecular terms. ${ }^{7-10}$ For the most part, nontarget tissues lacked receptors, and responsive tissues expressed and regulated the levels of these proteins. Recognition of hormone effects in cell types adjacent to those with receptors led to the appreciation of paracrine effects of steroid hormones. ${ }^{11-14}$ Further refinement of our understanding of sex hormone effects came with the development of the estrogen receptor (ER) null-mutation "knockout" mouse, ${ }^{15,16}$ which ironically was published the same year that a human subject was identified who lacked functional ER- $\alpha{ }^{17}$ Subsequent development of the PR knockout ${ }^{18}$ further facilitated our ability to assign specific actions to each steroid hormone. ${ }^{19,20}$ The availability of cells derived from each type of mouse provided confirming evidence regarding the paracrine actions of both $\mathrm{E}^{21}$ and $\mathrm{P}^{22}$ in the mouse uterus.

Clinical examples of deficiency of sex steroids or their receptors have also been well described. For example, inactivating mutations of the androgen receptor in the XY fetus results in a female appearance. ${ }^{23,24}$ Although deficiency of functional receptors for the other sex steroids are exceedingly rare, ${ }^{17}$ deficiency of $\mathrm{E}$ itself forms the basis for the wide range of disorders seen in rare women with deficient aromatase enzyme activity and all women at menopause. $\mathrm{P}$ deficiency states also occur frequently in women with anovulation. ${ }^{25-28}$ More subtle defects in $\mathrm{P}$ deficiency have long been postulated as a root cause of infertility and pregnancy wastage. ${ }^{29,30}$ More recently, deficiencies in $\mathrm{P}$ action rather than $\mathrm{P}$ amount have been suggested as a cause of infertility and pregnancy loss associated with the diagnosis of endometriosis. ${ }^{31}$

\section{PROGESTERONE AND ENDOMETRIAL PROTEINS}

The action of $\mathrm{P}$ in the endometrium is predicated on $\mathrm{E}$ priming. In response to $\mathrm{E}$, endometrial cells acquire the $\mathrm{PRs}$ that increase in number throughout the proliferative phase. $^{32} \mathrm{P}$ counters the action of $\mathrm{E}$ by reducing $\mathrm{E}$ receptors and inducing E-metabolizing enzymes. At the same time, $\mathrm{P}$ limits its own direct effect on endometrial epithelium but not stroma by greatly limiting expression of PR. These disparate effects on the stroma and epithelium drive the endometrium to a state of receptivity to embryo implantation. In nonconception cycles, further effects of $\mathrm{P}$ prepare the endometrium for menstruation and with $\mathrm{P}$ withdrawal, orchestrate the induction of a myriad of proteins responsible for digestion and shedding of the spent endometrium.

These changes in endometrial response to $\mathrm{P}$ have been recently characterized using advanced molecular microarray techniques. ${ }^{33,34}$ Such advancements could not have occurred, however, without the many sentinel studies on endometrial proteins that preceded them. Two of the first major endometrial proteins discovered were insulinlike growth factor-binding protein 1 (IGFBP-1, also known as placental protein 12) and glycodelin (also known as progesterone-associated endometrial protein or placental protein 14). Glycodelin and IGFBP-1 represent the most abundantly expressed proteins in response to $\mathrm{P}$, and both were initially but erroneously thought to originate from the placenta. ${ }^{35-43}$ As the name implies, IGFBP-1 binds the insulinlike growth factors, IGF-I and IGF-2, and can alter the growth factors' interactions with cognate receptors IGFR1 and IGFR2. ${ }^{44-46}$ IGFR1 and 2 are present in the epithelial compartment with maximal expression during the late secretory phase extending into pregnancy. ${ }^{47-49}$ IGFBP-1 is a major secretory product of the decidua in response to $\mathrm{P},{ }^{50-52}$ increased by epidermal growth factor (EGF) but inhibited by insulin. IGFBP-1 inhibits mitosis in endometrial stromal cells, ${ }^{53}$ and it may have a role in embryo attachment as well as invasion. $^{54}$

Glycodelin is maximally produced during the midsecretory phase in response to P. Aside from being a marker of $\mathrm{P}$ action, ${ }^{5-57}$ glycodelin likely plays a role in preventing late fertilization of oocytes, ${ }^{58}$ contributes to the immune response in pregnancy, ${ }^{59-61}$ and plays a role in epithelial differentiation. ${ }^{60}$ Glycodelin is associated 
with pinopode structures on receptive endometrium, and its expression is associated with downregulation of the PR-B isoform. ${ }^{61}$ Although the physiological roles for glycodelin and an understanding of its relative importance remains incomplete, the usefulness of this molecule to scientists lies in its close association with the actions of $\mathrm{P}$, providing a noninvasive measure of $\mathrm{P}$ activity during the menstrual cycle.

Complement proteins represent a major group of proteins that appear in the endometrium at the time of peak P. We and others have demonstrated that expression of complement $\mathrm{C} 3$ subunit, factor $\mathrm{B}$, and decay accelerating factor are all associated with the midsecretory phase endometrium, suggesting an important role for the alternative pathway during this cycle phase. ${ }^{62-65}$ Integrins, osteopontin, and CD44, also expressed during this time in the cycle, ${ }^{66,67}$ have been implicated as having a role in limiting complement activation. ${ }^{68-70}$ Thus, under physiological conditions, the effects of complement on the embryo are likely muted, but under certain conditions such as endometriosis, increased complement expression has been noted. ${ }^{71-73}$ Increased complement activation is associated with fetal wastage in animal models, leading some to speculate that this may be an underlying cause of pregnancy loss. ${ }^{74-76}$

A recent series of reports highlighted the expression of a class of innate immune receptors, the Toll-like receptors (TLRs), in the endometrium. ${ }^{77-80}$ Interestingly, one TLR, TLR3, appears to be limited largely to the epithelial layer of endometrium and cycle regulated in its expression with maximal expression during the mid and late secretory phases. The role of TLR3 at this time remains unclear, although it may simply be associated with increased innate immune activity to compensate for the relatively muted adaptive immune response. Interestingly, activation of TLR3 leads to a very robust expression of type I interferons, which are known to be important in embryo implantation of ruminant species, suggesting a potential role for TLR3 in the implantation process.

\section{PROGESTERONE AND UTERINE RECEPTIVITY}

$\mathrm{P}$ is absolutely essential for pregnancy as demonstrated by the early removal of the $\mathrm{CL}^{81}$ or by administration of PR antagonists such as RU-486 (mifepristone). ${ }^{82,83}$ During the early phases of the secretory phase, when ERs and PRs are plentiful, the endometrium differentiates into a secretory tissue, in response to both $\mathrm{E}$ and $\mathrm{P} .{ }^{84}$ By the midsecretory phase, ER abundance falls in all compartments, $\mathrm{PR} \mathrm{B}$ isoform is suppressed, and the stroma becomes the focus of $\mathrm{P}$ action. This loss of $\mathrm{E}$ action may determine which proteins are expressed in the epithelium, ${ }^{85}$ and P-induced paracrine factors from the stroma also dictate epithelial gene expression. ${ }^{86}$
What is clear from DNA microarray studies is that the receptive endometrium is a specialized structure that is both secretory and differentiated. Cell adhesion molecules (CAMs) are increased at the apical surface and loosened at the lateral attachments. Underlying stroma becomes "epithelialized" in preparation for trophoblast invasion. Specialized changes in the luminal epithelium provide an opportunity for embryo-endometrial interactions. None of these changes occur in the absence of $\mathrm{P}$.

Changes in the extracellular matrix (ECM) have been described throughout the menstrual cycle $^{87}$ extending into pregnancy, ${ }^{88}$ reflecting the role of CAMs in embryo-endometrial interactions. ${ }^{89}$ Integrins are cell-adhesion molecules that serve as receptors for extracellular matrix. ${ }^{90}$ Dynamic changes occur in integrin expression during the menstrual cycle and into pregnancy. ${ }^{91-94}$ The three amino acid motif arggly-asp (RGD) was implicated in implantation by several investigators. ${ }^{95-97}$ RGD is present on many ECM ligands in the receptive endometrium, including osteopontin, IGFBP-1, and fibronectin. ${ }^{98-101}$ RGD peptides were shown effectively to block implantation or attachment of embryos in vitro, suggesting a critical role of integrins and related ligands to endometrial receptivity. ${ }^{100-104}$

$\mathrm{P}$ actively blocks the actions and effectiveness of $\mathrm{E}$ in the endometrium. ${ }^{105}$ Aside from downregulation of E receptor, $\mathrm{P}$ induces $17 \beta$-hydroxysteroid dehydrogenase-type 2 (HSD17 $\beta 2)$ in endometrium that mediates the conversion of estradiol to the less active estrone. ${ }^{106}$ Thus both local E concentration and response are decreased. A loss of $\mathrm{E}$ action appears critical to the acquisition of endometrial receptivity, not only in humans, but among most, if not all, placental mammals.

In women with endometriosis ${ }^{107}$ or polycystic ovary syndrome (PCOS), ${ }^{108}$ increased $\mathrm{E}$ receptor abundance during the secretory phase appears to be a primary defect, suggesting the presence of $\mathrm{P}$ resistance. In both endometriosis and PCOS, ${ }^{109,110}$ deficient levels of HSD17 $\beta$ have also been described. Excessive production of $\mathrm{E}$ via aberrant expression of aromatase may contribute to this imbalance noted in certain pathological states. ${ }^{106}$ Whatever the mechanism, defects in $\mathrm{P}$ action alter the balance between $\mathrm{E}$ and $\mathrm{P}$ activity and likely influences numerous other steps in the acquisition of endometrial receptivity for embryo implantation.

$\mathrm{P}$ interacts with its receptor and other transcription factors including heat shock proteins, immunophilins, and coactivators that facilitate gene expression in target tissues. The immunophilin FKBP52 is a chaperone protein for PR and is critical to implantation in the mouse. ${ }^{111,112}$ Intriguing studies from the baboon model suggest that reduced FKBP52 is associated with endometriosis. This defect may explain in part the $\mathrm{P}$ resistance associated with this disease. ${ }^{31}$ 


\section{PROGESTERONE IN THE CLINIC}

Although $\mathrm{P}$ is essential for pregnancy, the amount of circulating or bioavailable $\mathrm{P}$ that is required is unknown. Normal standards of midluteal $\mathrm{P}$ have been assigned based on population studies, but the lower limits of $\mathrm{P}$ have only recently been explored. ${ }^{113}$ In this section we review the many facets of $\mathrm{P}$ deficiency and highlight the obstacles to a better understanding of what $\mathrm{P}$ deficiency actually implies.

\section{Luteal Phase Defect}

Luteal phase defect (LPD) is a disorder thought to be characterized by insufficient $\mathrm{P}$ production resulting in inadequate endometrial receptivity leading to infertility and pregnancy wastage. For many years, the histological appearance of the endometrium was assumed to be a sensitive measure of $\mathrm{P}$ action and thus endometrial function. The histological changes in the endometrium in response to ovulation were first examined by Rock and Bartlett in $1937 .{ }^{114}$ The hypothesis that alterations in endometrial histology would reflect functional capacity and thus fertility was first hypothesized by Georgeanna Seegar Jones in $1949 .{ }^{115}$ The criteria that defined the chronological dating of secretory endometrium was published a year later in 1950, in what has become the most cited paper in gynecologic literature. ${ }^{116}$ The endometrial biopsy was proposed as the most direct approach for the assessment of $\mathrm{P}$ effect. From the standpoint of the embryo, the end result and cumulative effects of $P$ are manifest in an endometrium that is functional and ready to accept the nascent embryo.

Based on the Noyes criteria, endometrial dating had been touted to be good predictive value for chronological dating. ${ }^{117,118}$ Unfortunately, the timing of the endometrial biopsy has changed over time; late endometrial biopsies were advocated prior to the availability of urinary ovulation predictor kits, whereas earlier biopsies are now advocated to maintain proximity to the window of implantation. ${ }^{119}$ Timing of the biopsy appears to alter the degree of variability in histological dating appearance, and the variability of histological dating has been shown to be so large that accuracy and reliability are not sufficient to justify the use of endometrial dating as a bioassay for $\mathrm{P}$ action. ${ }^{120-123}$ Thus, despite 60 years of study, the usefulness of endometrial histology for the assessment of infertility remains in doubt.

Because the theory of LPD centers on inadequate $\mathrm{P}$ production, it stands to reason that low circulating $\mathrm{P}$ concentrations at the midluteal phase might be considered the sine qua non for the diagnosis of LPD. Certainly a myriad of studies have examined the use of serum $\mathrm{P}$ in the evaluation of LPD. ${ }^{124}$ Using frequent $\mathrm{P}$ measurements, researchers have suggested that integrated $\mathrm{P}$ levels correlate with the quality (histology) of the secretory endometrium. ${ }^{125-128}$ Abraham suggested that three determinations of $\mathrm{P}>15 \mathrm{ng} / \mathrm{dL}$ was sufficient to exclude LPD. ${ }^{127}$ Others suggest that single determinations of $\mathrm{P} 4$ are sufficient. ${ }^{128}$ Levels as low as $3 \mathrm{ng} / \mathrm{mL}$ or as high as $10 \mathrm{ng} / \mathrm{mL}$ have been proposed. However, $\mathrm{P}$ is secreted in pulses and cleared relatively rapidly, resulting in large excursions in serum concentration. ${ }^{129}$ Thus, one or even a few measurements of serum $\mathrm{P}$ are not likely to be a reliable determinant of endometrial function. Furthermore, most of the evidence has rested on changes in endometrial histology, which, as discussed earlier, lacks sensitivity and specificity as tests of fertility.

If $\mathrm{P}$ insufficiency exists, alterations in CL function would likely be a cause. ${ }^{130}$ The functional capacity of the CL may depend on the follicle from which it was derived, and poor folliculogenesis could be a result of a poor quality oocyte and/or pituitary problems. Alternatively, delayed implantation due to endometrial dysfunction could lead to a delay in human chorionic gonadotropin signaling to the waiting CL. In this case, a perfectly normal $\mathrm{CL}$ may produce inadequate $\mathrm{P}$ by virtue of a late rescue from a tardy embryo. Such a mechanism appears quite likely based on population studies involving the timing of implantation. ${ }^{131}$ Any systemic disorder that alters ovulatory or endometrial function could potentially alter the quality of the follicular maturation, CL formation, CL rescue, or acquisition of uterine receptivity.

Other endocrine conditions may also impact on reproductive function. Hyperprolactinemia is an example of a systemic disorder linked to LPD. Wenner was the first to suggest the association between hyperprolactinemia and LPD. ${ }^{132}$ Subsequently, other authors have reported the finding of a shortened or inadequate luteal phase in hyperprolactinemia. ${ }^{133-138}$ Hypothyroidism may likewise alter the hypothalamicpituitary-ovarian axis and can be associated with elevated prolactin levels, ${ }^{139}$ leading to reduced $\mathrm{P}$ action and possibly LPD. ${ }^{140}$ Elevated androgen levels, such as those seen in PCOS, have been associated with LPD, ${ }^{141}$ suggesting a mechanism for the poor reproductive performance noted in this diagnosis. ${ }^{141}$ Even recreational running may lead to evidence of $\mathrm{P}$ insufficiency. ${ }^{142}$

As can be appreciated from the preceding discussion, problems with investigation of LPD include potential heterogeneity and overlap with other reproductive disorders. Furthermore, normal and abnormal individuals may be intrinsically different, so that a response to a defined amount of $\mathrm{P}$ in one woman may be significantly less than the response in someone else. To address the heterogeneity as well as the imprecision of serum $\mathrm{P}$ measurements, we recently studied normal fertile controls in an artificial hormonally controlled cycle. $^{113}$ These normal individuals maintained normal midsecretory endometrial histology as well as expression 
of selected marker genes despite steady-state levels of $\mathrm{P}$ of $\sim 4 \mathrm{ng} / \mathrm{mL}$.

Despite the lack of apparent difference between normal and low $\mathrm{P}$ in otherwise normal women in our protocol, $\mathrm{P}$ supplementation has proven benefit for fertility. During in vitro fertilization (IVF) cycles, $\mathrm{P}$ supplementation increases clinical pregnancy rates, especially within cycles using gonadotropin-releasing hormone analogues. ${ }^{143-145}$ Therefore, lowered $\mathrm{P}$ concentrations in IVF patients likely results in lowered fertility, and $\mathrm{P}$ supplementation restores fertility.

Because P levels approaching the lowest of those seen in ovulatory women supports normal endometrial structural and functional maturation in normal individuals, but infertility patients appear to benefit from higher $\mathrm{P}$ concentrations, it is possible that it is a difference in $\mathrm{P}$ response that determines LPD, rather than the absolute $\mathrm{P}$ concentration (Fig. 1). ${ }^{146}$ The explanation may be as simple as reduced or altered PR expression or as complex as epigenetic changes in specific genes. In an early study by McRae and Lyttle, steroid receptors for ER and PR were initially found be similar between women with normal cycles and those with LPD. ${ }^{147}$ Others report that both ER and PR levels are lower in LPD and that the PR:ER ratio is a reliable indicator of LPD. ${ }^{148}$ More recent work in this area is extensively covered elsewhere in this issue of Seminars in Reproductive Medicine.
Clearly, there remains much to study in this new area of $\mathrm{P}$ resistance.

As can be well appreciated from the preceding discussion, LPD, outside of an abnormally short luteal phase, is impossible to diagnose accurately with currently available clinical tools. Evidence suggests that assessment of circulating $\mathrm{P}$ is subject to difficulties in measurement. Furthermore, even if those difficulties could be obviated by frequent or integrated serum or urinary measurements, the critical issue of differences in endometrial response to $\mathrm{P}$ would be missed. Therefore biomarkers, whose endometrial production is inhibited or increased by $\mathrm{P}$, are the most logical area of development for the diagnosis of LPD.

\section{Biomarkers of Progesterone Action}

Many biomarkers of $\mathrm{P}$ activity have been proposed over the years. With the availability of specific mono- and polyclonal antibodies, immunohistochemistry was proposed to supplant histological dating. ${ }^{148-151}$ The advent of DNA microarray techniques and other advanced molecular techniques have dramatically increased the number of candidate biomarkers of $\mathrm{P}$ action. ${ }^{152-155}$ Infertility and recurrent pregnancy loss are often attributable to defects in implantation. ${ }^{131,156,158}$ Given the role of $\mathrm{P}$ on maintenance of pregnancy, and the

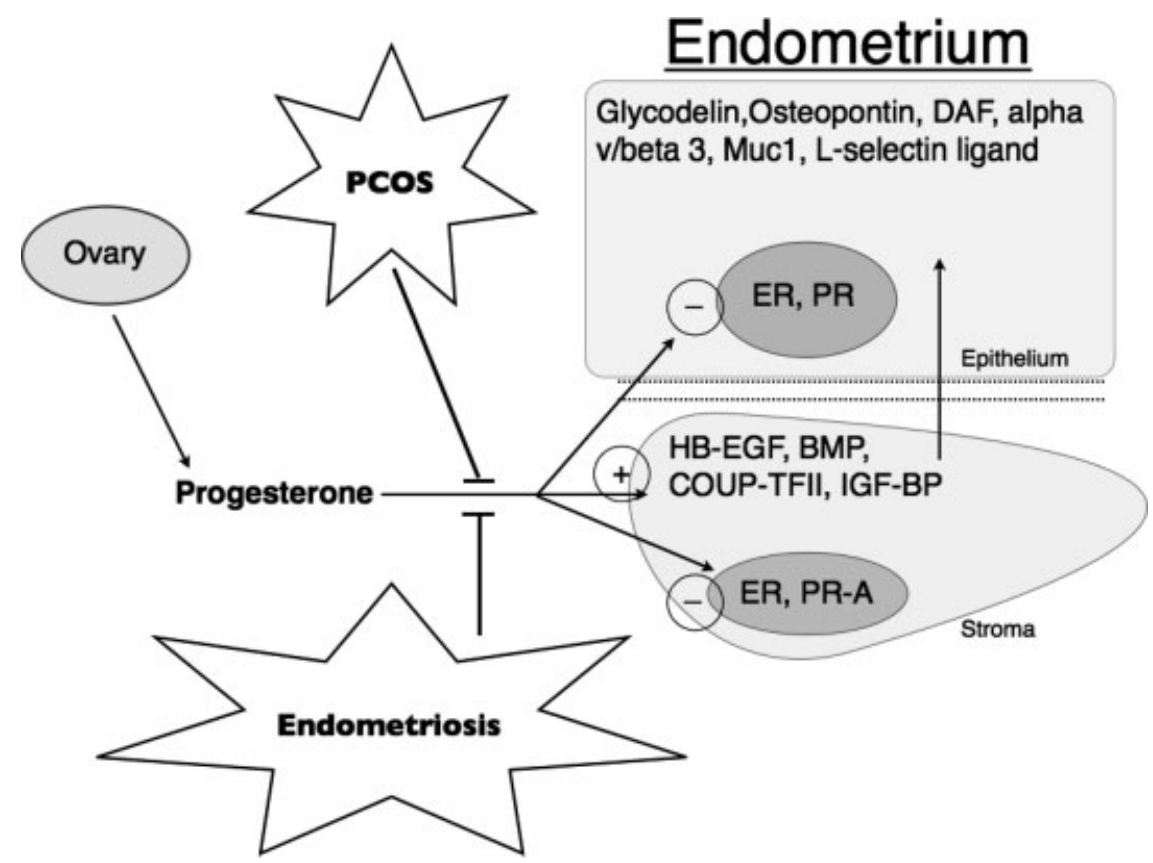

Figure 1 Progesterone (P) actions may be blocked in women with endometriosis or polycystic ovarian syndrome (PCOS). P, derived from the corpus luteum, acts differentially in the stromal versus epithelial cells, resulting in altered expression of several molecules important for embryo implantation. In epithelial cells, P downregulates all estrogen receptor (ER) and progesterone receptor (PR) forms, whereas in stromal cells, ER and PR-A are downregulated while PR-B persists. In women with PCOS or endometriosis, some of the actions of $\mathrm{P}$ may be altered, leading to diminished endometrial receptivity to embryo implantation. COUP-TFII, chicken ovalbumin upstream promoter transcription factor II; BMP, bone morphogenetic protein; DAF, decay accelerating factor; HB-EGF, heparin-binding EGF-like growth factor; IGFBP, insulin-like growth factor-binding protein. 
importance of synchronous interactions between the endometrium, CL, and embryo, delayed implantation for any reason could contribute to pregnancy wastage. ${ }^{131,157}$ It is estimated that $50 \%$ of all pregnancy failures during IVF cycles are due to defects in uterine receptivity. ${ }^{156,159}$ The use of biomarkers that measure the activity of $\mathrm{P}$ in the endometrium has gained favor and provides an alternative to histological dating alone. ${ }^{160-163}$

The first endometrial biomarkers were identified by two-dimensional electrophoresis using a radioactive label. ${ }^{164,165}$ Patterns of secreted histones assayed by thin layer chromatography were reported to be potential markers of P's effects on the endometrium. ${ }^{166,167}$ With the advent of specific monoclonal and polyclonal antibodies, and immunohistochemical methods as well as microarray technology, there are now a greatly expanded number of biomarkers to investigate. ${ }^{34,163,168-174}$

\section{Integrins and Cell Adhesion Molecules}

Dynamic changes in integrin expression during the menstrual cycle provide the opportunity to examine the functional quality of the endometrium during the time of peak $\mathrm{P}$ secretion. ${ }^{91,92}$ Integrins are arguably the best characterized markers of $\mathrm{P}$ effect on the endometrium. In 1992 we described both constitutive and cycledependent integrin changes that framed the window of implantation. ${ }^{91,92}$ Three integrins $(\alpha 1 \beta 1, \alpha 4 \beta 1$, and $\alpha v \beta 3)$ are coexpressed in receptive endometrium during the time of maximal endometrial receptivity. The $\alpha v \beta 3$ integrin appears at the opening of the window of implantation around cycle day 20 or 21 and is present on the apical pole of the luminal epithelium corresponding to the site of pinopode expression. This integrin is regulated by EGF and EGF-related molecules, and by the transcription factor Hoxa10. ${ }^{65,175,176}$ Of note, the appearance of this integrin corresponds closely to the downregulation of $\mathrm{ER} \alpha$ in receptive endometrium. In cycles where $\mathrm{P}$ fails effectively to downregulate ER, this integrin does not appear normally on cycle day $20 .{ }^{106}$ Recent data also suggests that $\alpha v \beta 3$ integrin associates with osteopontin. This secreted protein also appears around days 19 to 20 , is regulated by $\mathrm{P}$, and may bind to the $\alpha \mathrm{v} / \beta 3$ integrin through its RGD sequence. ${ }^{177}$

\section{Selectins/Cadherins}

L-selectin is a member of the selectin family and may be a key molecule involved in the initial attachment of the embryo. ${ }^{178}$ The ligand for this selectin, a sialyl glycoprotein, is $\mathrm{P}$ regulated and appears on the receptive endometrium at the midluteal phase, and it is recognized by the monoclonal antibody MECA-79. The distribution of the antigen recognized by MECA79 has now been studied in normal cycling women during the menstrual cycle ${ }^{179}$ and may be a clinically useful marker of endometrial receptivity and $\mathrm{P}$ action. ${ }^{180}$

Another class of cell-adhesion molecules in the endometrium is the cadherins. These are calciumdependent transmembrane molecules that have been designated as E-, P,- and N-cadherins. On most normal epithelial cells E-cadherin is involved in lateral attachments between cells and regulated by intracellular calcium. The link to $\mathrm{P}$ in endometrium is likely through the action of calcitonin, a $\mathrm{P}$-induced protein in both human and rodent endometrium. ${ }^{181,182}$ Calcitonin functions to increase intracellular calcium that in turn attenuates E-cadherin expression at the time of peak $\mathrm{P}$ and implantation. ${ }^{183}$ Another cadherin, cadherin 11, is present in endometrial stroma and also regulated by $\mathrm{P}$. This key marker of decidualization has been proposed as a mediator of endometrial-trophoblast interaction. ${ }^{184,185}$

\section{Growth Factors}

$\mathrm{P}$ appears to regulate other key pathways through its influence on growth factors or cytokines. The EGF family of growth factors and their receptors play an important role during implantation. ${ }^{186,187}$ In the mouse uterus, heparin-binding EGF-like growth factor (HBEGF) is expressed around the blastocyst during early implantation. HB-EGF has both a soluble and transmembrane forms. As a transmembrane "receptor," HBEGF could serve as an embryonic receptor through the EGF receptor on the embryonic epithelium. ${ }^{188}$ As a soluble factor, HB-EGF significantly improves embryonic development. ${ }^{188}$ HB-EGF has been implicated in the regulation of key endometrial receptivity proteins. ${ }^{67,189} \mathrm{We}$ showed that $\mathrm{P}$ regulates the expression of HB-EGF in endometrial stroma and linked its expression to the regulation of the $\alpha \mathrm{v} / \beta 3$ integrin via HOXA10 using a paracrine mechanism of action.

\section{SUMMARY REMARKS}

$\mathrm{P}$ action on the endometrium is essential for embryo implantation and pregnancy maintenance. These "progestational" functions of $\mathrm{P}$ are achieved by direct and indirect regulation of many molecules known to play important roles in embryo implantation. At some lower threshold of concentration, there will not be sufficient $\mathrm{P}$ action on the endometrium, resulting in infertility or pregnancy loss. Recent evidence demonstrates that in young fertile women, the minimum $\mathrm{P}$ concentration required for normal endometrial maturation is very low, perhaps lower than that seen in ovulatory women. This finding suggests that low $\mathrm{P}$, as an isolated abnormality, is not likely to be a common cause of infertility or pregnancy loss. Recent data demonstrating altered effects of $\mathrm{P}$ on endometrium of women with endometriosis suggests that resistance to some actions of $\mathrm{P}$ may more 
commonly underlie reproductive disorders. The hypothesis of $\mathrm{P}$ resistance as an important pathophysiological process remains an attractive, but unproven hypothesis with currently unclear mechanisms. However, if the hypothesis is proven, it will open a new avenue of approach to clinical therapies for reproductive disorders.

\section{ACKNOWLEDGMENTS}

This work was supported by the Eunice Kennedy Shriver NICHD/NIH through cooperative agreement U54HD035041-11 as part of the Specialized Cooperative Centers Program in Reproduction and Infertility Research.

\section{REFERENCES}

1. Gellersen B, Fernandes MS, Brosens JJ. Non-genomic progesterone actions in female reproduction. Hum Reprod Update 2009

2. Klein M. [Berthold's article: Transplantation of the testes (1849)]. Arch Anat Histol Embryol 1968;51(1):379-386

3. Allen E, Doisey EA. Landmark article Sept. 8, 1923. An ovarian hormone: preliminary report on its localization, extraction and partial purification, and action in test animals. JAMA 1983;250:2681-2683

4. Hisaw FL, Meyer RK, Weichert CK. Inhibition of ovulation and associated histologic changes. Proc Soc Exp Biol Med 1928;20:754-756

5. Hisaw FL, Leonard SL. Production of a premenstrual endometrium in castrated monkeys by ovarian hormones. Proc Soc Exp Biol Med 1930;27:400-403

6. Allen WM, Corner GW. Physiology of the corpus luteum. Am J Obstet Gynecol 2005;193:1574

7. Jensen EV, DeSombre ER. Estrogen-receptor interaction. Science 1973;182:126-134

8. Gorski J, Toft D, Shyamala G, Smith D, Notides A. Hormone receptors: studies on the interaction of estrogen with the uterus. Recent Prog Horm Res 1968;24:45-80

9. O'Malley BW, Sherman MR, Toft DO. Progesterone "receptors" in the cytoplasm and nucleus of chick oviduct target tissue. Proc Natl Acad Sci U S A 1970;67:501-508

10. O'Malley BW, Means AR. Female steroid hormones and target cell nuclei. Science 1974;183(125):610-620

11. Mueller GC, Herranen AM, Jervell KF. Studies on the mechanism of action of estrogens. Recent Prog Horm Res 1958;14:95-129; discussion 130-129

12. Jensen EV. Proceedings of the 4th International Congress of Biochemistry; Vol 15:Oxford, United Kingdom: Pergamon Press; 1958

13. Jensen EV, Jacobson HI. Fate of steroid receptor estrogens in target tissues. In: Pincus G, Vollmer EP, eds. Biological Activities of Steroids in Relation to Cancer. New York, NY: Academic Press; 1960

14. Jensen EV, DeSombre ER. Estrogen-receptor interaction. Science 1973;182:126-134

15. Lubahn DB, Moyer JS, Golding TS, Couse JF, Korach KS, Smithies O. Alteration of reproductive function but not prenatal sexual development after insertional disruption of the mouse estrogen receptor gene. Proc Natl Acad Sci U S A 1993;90(23):11162-11166

16. Korach KS. Insights from the study of animals lacking functional estrogen receptor. Science 1994;266(5190):15241527

17. Smith EP, Boyd J, Frank GR, et al. Estrogen resistance caused by a mutation in the estrogen-receptor gene in a man. N Engl J Med 1994;331(16):1056-1061

18. Korach KS. Insights from the study of animals lacking functional estrogen receptor. Science 1994;266(5190):15241527

19. Conneely OM, Mulac-Jericevic B, DeMayo F, Lydon JP, O'Malley BW. Reproductive functions of progesterone receptors. Recent Prog Horm Res 2002;57:339-355

20. Cooke PS, Buchanan DL, Lubahn DB, Cunha GR. Mechanism of estrogen action: lessons from the estrogen receptor- $\alpha$ knockout mouse. Biol Reprod 1998;59(3):470475

21. Kurita T, Lee KJ, Cooke PS, Taylor JA, Lubahn DB, Cunha GR. Paracrine regulation of epithelial progesterone receptor by estradiol in the mouse female reproductive tract. Biol Reprod 2000;62(4):821-830

22. Kurita T, Young P, Brody JR, Lydon JP, O'Malley BW, Cunha GR. Stromal progesterone receptors mediate the inhibitory effects of progesterone on estrogen-induced uterine epithelial cell deoxyribonucleic acid synthesis. Endocrinology 1998;139(11):4708-4713

23. Milin B, Roy AK. Androgen "receptor" in rat liver: cytosol "receptor" deficiency in pseudohermaphrodite male rats. Nat New Biol 1973;242(121):248-250

24. Brown TR, Lubahn DB, Wilson EM, Joseph DR, French FS, Migeon CJ. Deletion of the steroid-binding domain of the human androgen receptor gene in one family with complete androgen insensitivity syndrome: evidence for further genetic heterogeneity in this syndrome. Proc Natl Acad Sci U S A 1988;85(21):8151-8155

25. Erickson GF, Yen SSC. The polycystic ovary syndrome. In: Adashi EY, Leung PCK, eds. The Ovary. New York, NY: Raven Press; 1993

26. Franks S. Polycystic ovary syndrome. Arch Dis Child 1997; 77(1):89-90

27. Homburg R. Polycystic ovary syndrome. Best Pract Res Clin Obstet Gynaecol 2008;22:261-274

28. Navaratnarajah R, Pillay OC, Hardiman P. Polycystic ovary syndrome and endometrial cancer. Semin Reprod Med 2008;26(1):62-71

29. Fritz MA, Lessey BA. Defective luteal function. In: Fraser IS, ed. Estrogens and Progestogens in Clinical Practice. Vol1. London, United Kingdom: Churchill Livingstone; 1998

30. Jones GE. Some newer aspects of the management of infertility. J Am Med Assoc 1949;141:1123-1129

31. Burney RO, Talbi S, Hamilton AE, et al. Gene expression analysis of endometrium reveals progesterone resistance and candidate susceptibility genes in women with endometriosis. Endocrinology 2007;148(8):3814-3826

32. Lessey BA, Killam AP, Metzger DA, Haney AF, Greene GL, McCarty KS Jr. Immunohistochemical analysis of human uterine estrogen and progesterone receptors throughout the menstrual cycle. J Clin Endocrinol Metab 1988;67(2): 334-340

33. Talbi S, Hamilton AE, Vo KC, et al. Molecular phenotyping of human endometrium distinguishes menstrual cycle phases and underlying biological processes in 
normo-ovulatory women. Endocrinology 2006;147(3): 1097-1121

34. Catalano RD, Critchley $\mathrm{HO}$, Heikinheimo $\mathrm{O}$, et al. Mifepristone induced progesterone withdrawal reveals novel regulatory pathways in human endometrium. Mol Hum Reprod 2007;13(9):641-654

35. Joshi SG, Ebert KM, Smith RA. Properties of the progestagen-dependent protein of the human endometrium. J Reprod Fertil 1980;59(2):287-296

36. Joshi SG, Ebert KM, Swartz DP. Detection and synthesis of a progestagen-dependent protein in human endometrium. J Reprod Fertil 1980;59(2):273-285

37. Joshi SG. Progestin-regulated proteins of the human endometrium. Semin Reprod Endocrinol 1983;1:221

38. Julkunen M, Raikar RS, Joshi SG, Bohn H, Seppälä M. Placental protein 14 and progestagen-dependent endometrial protein are immunologically indistinguishable. Hum Reprod 1986;1(1):7-8

39. Bohn H, Kraus W. Isolation and characterization of a new placenta specific protein (PP12). Arch Gynecol 1980;229: 279-291

40. Rutanen EM, Koistinen R, Seppälä M, Julkunen M, Suikkari AM, Huhtala ML. Progesterone-associated proteins PP12 and PP14 in the human endometrium. J Steroid Biochem 1987;27(1-3):25-31

41. Bischof P. Three pregnancy proteins (PP12, PP14, and PAPP-A): their biological and clinical relevance. Am J Perinatol 1989;6(2):110-116

42. Julkunen M, Koistinen R, Sjöberg J, Rutanen EM, Wahlström T, Seppälä M. Secretory endometrium synthesizes placental protein 14. Endocrinology 1986;118(5):17821786

43. Rutanen EM, Koistinen R, Sjöberg J, et al. Synthesis of placental protein 12 by human endometrium. Endocrinology 1986;118(3):1067-1071

44. Giudice LC, Lamson G, Rosenfeld RG, Irwin JC. Insulinlike growth factor-II (IGF-II) and IGF binding proteins in human endometrium. Ann N Y Acad Sci 1991;626:295-307

45. Seppälä M, Koistinen R, Rutanen EM. Uterine endocrinology and paracrinology: insulin-like growth factor binding protein-1 and placental protein 14 revisited. Hum Reprod 1994;9(5):917-925

46. Rutanen EM, Pekonen F, Nyman T, Wahlström T. Insulin-like growth factors and their binding proteins in benign and malignant uterine diseases. Growth Regul 1993; 3(1):74-77

47. Giudice LC, Dsupin BA, Jin IH, Vu TH, Hoffman AR. Differential expression of messenger ribonucleic acids encoding insulin-like growth factors and their receptors in human uterine endometrium and decidua. J Clin Endocrinol Metab 1993;76(5):1115-1122

48. Bell SC. The insulin-like growth factor binding proteinsthe endometrium and decidua. Ann N Y Acad Sci 1991;622: 120-137

49. Tseng L, Gao JG, Chen R, Zhu HH, Mazella J, Powell DR. Effect of progestin, antiprogestin, and relaxin on the accumulation of prolactin and insulin-like growth factorbinding protein-1 messenger ribonucleic acid in human endometrial stromal cells. Biol Reprod 1992;47(3):441-450

50. Irwin JC, de las Fuentes L, Giudice LC. Growth factors and decidualization in vitro. Ann N Y Acad Sci 1994;734:7-18

51. Frost RA, Mazella J, Tseng L. Insulin-like growth factor binding protein- 1 inhibits the mitogenic effect of insulin- like growth factors and progestins in human endometrial stromal cells. Biol Reprod 1993;49(1):104-111

52. Irwin JC, Suen LF, Martina NA, Mark SP, Giudice LC. Role of the IGF system in trophoblast invasion and preeclampsia. Hum Reprod 1999;14(Suppl 2):90-96

53. Li TC, Dalton C, Hunjan KS, Warren MA, Bolton AE. The correlation of placental protein 14 concentrations in uterine flushing and endometrial morphology in the periimplantation period. Hum Reprod 1993;8(11):1923-1927

54. Klentzeris LD, Bulmer JN, Seppälä M, Li TC, Warren MA, Cooke ID. Placental protein 14 in cycles with normal and retarded endometrial differentiation. Hum Reprod 1994;9(3):394-398

55. Dalton CF, Laird SM, Serle E, et al. The measurement of CA 125 and placental protein 14 in uterine flushings in women with recurrent miscarriage; relation to endometrial morphology. Hum Reprod 1995;10(10):2680-2684

56. Oehninger S, Coddington CC, Hodgen GD, Seppala M. Factors affecting fertilization: endometrial placental protein 14 reduces the capacity of human spermatozoa to bind to the human zona pellucida. Fertil Steril 1995;63(2):377-383

57. Clark GF, Oehninger S, Patankar MS, et al. A role for glycoconjugates in human development: the human fetoembryonic defence system hypothesis. Hum Reprod 1996; 11(3):467-473

58. Karande AA, Mukhopadhyay D, Jayachandran R, Sundarraj S, Alok A. Mechanism of the immunomodulatory activity of glycodelin. Indian J Physiol Pharmacol 2005;49(3):271-283

59. Alok A, Mukhopadhyay D, Karande AA. Glycodelin A, an immunomodulatory protein in the endometrium, inhibits proliferation and induces apoptosis in monocytic cells. Int J Biochem Cell Biol 2009;41(5):1138-1147

60. Seppälä M, Taylor RN, Koistinen H, Koistinen R, Milgrom E. Glycodelin: a major lipocalin protein of the reproductive axis with diverse actions in cell recognition and differentiation. Endocr Rev 2002;23(4):401-430

61. Stavreus-Evers A, Mandelin E, Koistinen R, et al. Glycodelin is present in pinopodes of receptive-phase human endometrium and is associated with down-regulation of progesterone receptor B. Fertil Steril 2006;85(6):1803-1811

62. Hasty LA, Lessey BA, Pruksananonda K, et al. The hormonal regulation of complement components throughout the menstrual cycle. Proc of the Soc Gynecol Invest 1992

63. Hasty LA, Brockman WW, Lambris JD, Lyttle CR. Hormonal regulation of complement factor B in human endometrium. Am J Reprod Immunol 1993;30(2-3):63-67

64. Hasty LA, Lambris JD, Lessey BA, Pruksananonda K, Lyttle CR. Hormonal regulation of complement components and receptors throughout the menstrual cycle. Am J Obstet Gynecol 1994;170(1 Pt 1):168-175

65. Young SL, Lessey BA, Fritz MA, et al. In vivo and in vitro evidence suggest that $\mathrm{HB}-\mathrm{EGF}$ regulates endometrial expression of human decay-accelerating factor. J Clin Endocrinol Metab 2002;87(3):1368-1375

66. Apparao KB, Murray MJ, Fritz MA, et al. Osteopontin and its receptor alphavbeta(3) integrin are coexpressed in the human endometrium during the menstrual cycle but regulated differentially. J Clin Endocrinol Metab 2001;86(10):49915000

67. Lessey BA, Castelbaum AJ. Integrins and implantation in the human. Rev Endocr Metab Disord 2002;3(2):107-117

68. Fedarko NS, Fohr B, Robey PG, Young MF, Fisher LW. Factor $\mathrm{H}$ binding to bone sialoprotein and osteopontin 
enables tumor cell evasion of complement-mediated attack. J Biol Chem 2000;275(22):16666-16672

69. Fisher LW, Torchia DA, Fohr B, Young MF, Fedarko NS. Flexible structures of SIBLING proteins, bone sialoprotein, and osteopontin. Biochem Biophys Res Commun 2001; 280(2):460-465

70. Jain A, Karadag A, Fohr B, Fisher LW, Fedarko NS. Three SIBLINGs (small integrin-binding ligand, N-linked glycoproteins) enhance factor H's cofactor activity enabling MCP-like cellular evasion of complement-mediated attack. J Biol Chem 2002;277(16):13700-13708

71. Isaacson KB, Coutifaris C, Garcia CR, Lyttle CR. Production and secretion of complement component 3 by endometriotic tissue. J Clin Endocrinol Metab 1989;69(5): 1003-1009

72. Isaacson KB, Galman M, Coutifaris C, Lyttle CR. Endometrial synthesis and secretion of complement component -3 by patients with and without endometriosis. Fertil Steril 1990;53(5):836-841

73. Tao XJ, Sayegh RA, Isaacson KB. Increased expression of complement component 3 in human ectopic endometrium compared with the matched eutopic endometrium. Fertil Steril 1997;68(3):460-467

74. Holers VM, Girardi G, Mo L, et al. Complement C3 activation is required for antiphospholipid antibody-induced fetal loss. J Exp Med 2002;195(2):211-220

75. Xu C, Mao D, Holers VM, Palanca B, Cheng AM, Molina H. A critical role for murine complement regulator Crry in fetomaternal tolerance. Science 2000; 287(5452):498-501

76. Molina H. The murine complement regulator Crry: new insights into the immunobiology of complement regulation. Cell Mol Life Sci 2002;59(2):220-229

77. Jorgenson RL, Young SL, Lesmeister MJ, Lyddon TD, Misfeldt ML. Human endometrial epithelial cells cyclically express Toll-like receptor 3 (TLR3) and exhibit TLR3dependent responses to dsRNA. Hum Immunol 2005;66(5): 469-482

78. Fazeli A, Bruce C, Anumba DO. Characterization of Tolllike receptors in the female reproductive tract in humans. Hum Reprod 2005;20(5):1372-1378

79. Schaefer TM, Desouza K, Fahey JV, Beagley KW, Wira CR. Toll-like receptor (TLR) expression and TLR-mediated cytokine/chemokine production by human uterine epithelial cells. Immunology 2004;112(3):428436

80. Pioli PA, Amiel E, Schaefer TM, Connolly JE, Wira CR, Guyre PM. Differential expression of Toll-like receptors 2 and 4 in tissues of the human female reproductive tract. Infect Immun 2004;72(10):5799-5806

81. Csapo AI, Pulkkinen M. Indispensability of the human corpus luteum in the maintenance of early pregnancy. Luteectomy evidence. Obstet Gynecol Surv 1978;33(2): 69-81

82. Baulieu EE. Contragestion and other clinical applications of RU 486, an antiprogesterone at the receptor. Science 1989;245(4924):1351-1357

83. Baulieu EE. RU486: a compound that gets itself talked about. Hum Reprod 1994;9(Suppl 1):1-6

84. Somkuti SG, Yuan L, Fritz MA, Lessey BA. Epidermal growth factor and sex steroids dynamically regulate a marker of endometrial receptivity in Ishikawa cells. J Clin Endocrinol Metab 1997;82(7):2192-2197
85. Kurihara I, Lee DK, Petit FG, et al. COUP-TFII mediates progesterone regulation of uterine implantation by controlling ER activity. PLoS Genet 2007;3(6):e102

86. Lessey BA. Two pathways of progesterone action in the human endometrium: implications for implantation and contraception. Steroids 2003;68(10-13):809-815

87. Aplin JD, Charlton AK, Ayad S. An immunohistochemical study of human endometrial extracellular matrix during the menstrual cycle and first trimester of pregnancy. Cell Tissue Res 1988;253(1):231-240

88. Ruck P, Marzusch K, Kaiserling E, et al. Distribution of cell adhesion molecules in decidua of early human pregnancy. An immunohistochemical study. Lab Invest 1994;71(1): 94-101

89. Turpeenniemi-Hujanen T, Feinberg RF, Kauppila A, Puistola U. Extracellular matrix interactions in early human embryos: implications for normal implantation events. Fertil Steril 1995;64(1):132-138

90. Albelda SM, Buck CA. Integrins and other cell adhesion molecules. FASEB J 1990;4:2868-2880

91. Lessey BA, Damjanovich L, Coutifaris C, Castelbaum A, Albelda SM, Buck CA. Integrin adhesion molecules in the human endometrium. Correlation with the normal and abnormal menstrual cycle. J Clin Invest 1992;90(1):188-195

92. Lessey BA, Castelbaum AJ, Buck CA, Lei Y, Yowell CW, Sun J. Further characterization of endometrial integrins during the menstrual cycle and in pregnancy. Fertil Steril 1994;62(3):497-506

93. Tabibzadeh S. Patterns of expression of integrin molecules in human endometrium throughout the menstrual cycle. Hum Reprod 1992;7(6):876-882

94. Damsky C, Sutherland A, Fisher S. Extracellular matrix 5: adhesive interactions in early mammalian embryogenesis, implantation, and placentation. FASEB J 1993;7(14):13201329

95. Armant DR, Kaplan HA, Mover H, Lennarz WJ. The effect of hexapeptides on attachment and outgrowth of mouse blastocysts cultured in vitro: evidence for the involvement of the cell recognition tripeptide Arg-GlyAsp. Proc Natl Acad Sci U S A 1986;83(18):6751-6755

96. Illera MJ, Cullinan E, Gui Y, Yuan L, Beyler SA, Lessey BA. Blockade of the alpha(v)beta(3) integrin adversely affects implantation in the mouse. Biol Reprod 2000;62(5):12851290

97. Illera MJ, Gui YT, Mohammad A, et al. Perturbation of implantation rate by neutralization of the $\alpha \mathrm{v} \beta 3$ vitronectin receptor in rabbits. J Soc Gynecol Invest 1999;379:143A

98. Bronson RA, Fusi FM. Integrins and human reproduction. Mol Hum Reprod 1996;2(3):153-168

99. Yelian FD, Yang Y, Hirata JD, Schultz JF, Armant DR. Molecular interactions between fibronectin and integrins during mouse blastocyst outgrowth. Mol Reprod Dev 1995;41(4):435-448

100. Jones JI, Gockerman A, Busby WH Jr, Wright G, Clemmons DR. Insulin-like growth factor binding protein 1 stimulates cell migration and binds to the alpha 5 beta 1 integrin by means of its Arg-Gly-Asp sequence. Proc Natl Acad Sci U S A 1993;90(22):10553-10557

101. Schultz JF, Armant DR. $\beta$ 1- and $\beta$ 3-class integrins mediate fibronectin binding activity at the surface of developing mouse peri-implantation blastocysts. Regulation by ligand-induced mobilization of stored receptor. J Biol Chem 1995;270(19):11522-11531 
102. Yelian FD, Yang Y, Hirata JD, Schultz JF, Armant DR. Molecular interactions between fibronectin and integrins during mouse blastocyst outgrowth. Mol Reprod Dev 1995; 41(4):435-448

103. Illera MJ, Lorenzo PL, Gui YT, Beyler SA, Apparao KB, Lessey BA. A role for alphavbeta3 integrin during implantation in the rabbit model. Biol Reprod 2003;68(3): 766-771

104. Sutherland AE, Calarco PG, Damsky CH. Developmental regulation of integrin expression at the time of implantation in the mouse embryo. Development 1993;119(4): $1175-1186$

105. Tseng L, Gurpide E. Effects of progestins on estradiol receptor levels in human endometrium. J Clin Endocrinol Metab 1975;41(2):402-404

106. Bulun SE, Gurates B, Fang Z, et al. Mechanisms of excessive estrogen formation in endometriosis. J Reprod Immunol 2002;55(1-2):21-33

107. Noble LS, Simpson ER, Johns A, Bulun SE. Aromatase expression in endometriosis. J Clin Endocrinol Metab 1996; 81(1):174-179

108. Leon L, Bacallao K, Gabler F, Romero C, Valladares L, Vega M. Activities of steroid metabolic enzymes in secretory endometria from untreated women with polycystic ovary syndrome. Steroids 2008;73(1):88-95

109. Kitawaki J, Noguchi T, Amatsu T, et al. Expression of aromatase cytochrome $\mathrm{P} 450$ protein and messenger ribonucleic acid in human endometriotic and adenomyotic tissues but not in normal endometrium. Biol Reprod 1997;57(3): 514-519

110. Kitawaki J, Kusuki I, Koshiba H, Tsukamoto K, Honjo H. Expression of aromatase cytochrome P450 in eutopic endometrium and its application as a diagnostic test for endometriosis. Gynecol Obstet Invest 1999;48(Suppl 1): $21-28$

111. Tranguch S, Cheung-Flynn J, Daikoku T, et al. Cochaperone immunophilin FKBP52 is critical to uterine receptivity for embryo implantation. Proc Natl Acad Sci U S A 2005; 102(40):14326-14331

112. Tranguch S, Wang H, Daikoku T, Xie H, Smith DF, Dey SK. FKBP52 deficiency-conferred uterine progesterone resistance is genetic background and pregnancy stage specific. J Clin Invest 2007;117(7):1824-1834

113. Usadi RS, Groll JM, Lessey BA, et al. Endometrial development and function in experimentally induced luteal phase deficiency. J Clin Endocrinol Metab 2008;93(10): 4058-4064

114. Rock J, Bartlett MK. Biopsy studies of human endometrium, criterion of dating and information about amenorrhea, menorrhagia, and tissue ovulation. J Am Med Assoc 1937;108:2022-2028

115. Jones GE. Some newer aspects of management of infertility. J Am Med Assoc 1949;141:1123-1129

116. Noyes RW, Hertig AI, Rock J. Dating the endometrial biopsy. Fertil Steril 1950;1:3-25

117. Noyes RW, Haman JO. Accuracy of endometrial dating; correlation of endometrial dating with basal body temperature and menses. Fertil Steril 1953;4(6):504-517

118. Castelbaum AJ, Lessey BA. Insights into the evaluation of the luteal phase. In: Diamond MP, ed. Infertility and Reproductive Medicine. Vol 6. Philadelphia, PA: WB Saunders; 1995:199-213
119. Castelbaum AJ, Wheeler J, Coutifaris CB, Mastroianni L Jr, Lessey BA. Timing of the endometrial biopsy may be critical for the accurate diagnosis of luteal phase deficiency. Fertil Steril 1994;61(3):443-447

120. Murray MJ, Meyer WR, Zaino RJ, et al. A critical analysis of the accuracy, reproducibility, and clinical utility of histologic endometrial dating in fertile women. Fertil Steril 2004;81(5):1333-1343

121. Scott RT, Snyder RR, Bagnall JW, Reed KD, Adair CF, Hensley SD. Evaluation of the impact of intraobserver variability on endometrial dating and the diagnosis of luteal phase defects. Fertil Steril 1993;60(4):652-657

122. Coutifaris C, Myers ER, Guzick DS, et al; NICHD National Cooperative Reproductive Medicine Network. Histological dating of timed endometrial biopsy tissue is not related to fertility status. Fertil Steril 2004;82(5):12641272

123. Castelbaum AJ, Lessey BA. Insights into the evaluation of the luteal phase. Infert Reprod Med Clin No Am 1994; 6:199

124. Soules MR, McLachlan RI, Ek M, Dahl KD, Cohen NL, Bremner WJ. Luteal phase deficiency: characterization of reproductive hormones over the menstrual cycle. J Clin Endocrinol Metab 1989;69(4):804-812

125. Li TC, Lenton EA, Dockery P, Cooke ID. A comparison of some clinical and endocrinological features between cycles with normal and defective luteal phases in women with unexplained infertility. Hum Reprod 1990;5(7):805810

126. Hecht BR, Bardawil WA, Khan-Dawood FS, Dawood MY. Luteal insufficiency: correlation between endometrial dating and integrated progesterone output in clomiphene citrateinduced cycles. Am J Obstet Gynecol 1990;163(6 Pt 1): 1986-1991

127. Abraham GE, Maroulis GB, Marshall JR. Evaluation of ovulation and corpus luteum function using measurements of plasma progesterone. Obstet Gynecol 1974;44(4):522525

128. Hull MG, Savage PE, Bromham DR, Ismail AA, Morris AF. The value of a single serum progesterone measurement in the midluteal phase as a criterion of a potentially fertile cycle ("ovulation") derived form treated and untreated conception cycles. Fertil Steril 1982;37(3):355-360

129. Filicori M, Butler JP, Crowley WF Jr. Neuroendocrine regulation of the corpus luteum in the human. Evidence for pulsatile progesterone secretion. J Clin Invest 1984;73(6): 1638-1647

130. Nakajima ST, Gibson M. Pathophysiology of luteal-phase deficiency in human reproduction. Clin Obstet Gynecol 1991;34(1):167-179

131. Wilcox AJ, Baird DD, Weinberg CR. Time of implantation of the conceptus and loss of pregnancy. N Engl J Med 1999; 340(23):1796-1799

132. Wenner R. Les antiprolactines. Gynecologie 1974;25(2): 229-231

133. Franks S, Murray MAF, Jequier AM, Steele SJ, Nabarro JD, Jacobs HS. Incidence and significance of hyperprolactinaemia in women with amenorrhea. Clin Endocrinol (Oxf) 1975; 4(6):597-607

134. Corenblum B, Pairandeau N, Shewchuk AB. Prolactin hypersecretion and short luteal phase defects. Obstet Gynecol 1976;47:486-488 
135. Spark RF, Pallotta J, Naftolin F, Clemens R. Galactorrheaamenorrhea syndromes: etiology and treatment. Ann Intern Med 1976;84(5):532-537

136. Mühlenstedt D, Bohnet HG, Hanker JP, Schneider HP. Short luteal phase and prolactin. Int J Fertil 1978;23(3): 213-218

137. del Pozo E, Wyss H, Tollis G, Alcañiz J, Campana A, Naftolin F. Prolactin and deficient luteal function. Obstet Gynecol 1979;53(3):282-286

138. Edwards CRW, Forsyth IA, Besser GM. Amenorrhoea, galactorrhoea, and primary hypothyroidism with high circulating levels of prolactin. BMJ 1971;3(5772):462464

139. Daly DC, Walters CA, Soto-Albors CE, Riddick DH. Endometrial biopsy during treatment of luteal phase defects is predictive of therapeutic outcome. Fertil Steril 1983;40(3): 305-310

140. Sherman BM, Korenman SG. Measurement of plasma LH, FSH, estradiol and progesterone in disorders of the human menstrual cycle: the short luteal phase. J Clin Endocrinol Metab 1974;38(1):89-93

141. Homburg R, Armar NA, Eshel A, Adams J, Jacobs HS. Influence of serum luteinising hormone concentrations on ovulation, conception, and early pregnancy loss in polycystic ovary syndrome. BMJ 1988;297(6655):1024-1026

142. De Souza MJ, Van Heest J, Demers LM, Lasley BL. Luteal phase deficiency in recreational runners: evidence for a hypometabolic state. J Clin Endocrinol Metab 2003;88(1): 337-346

143. Practice Committee of the American Society for Reproductive Medicine. Progesterone supplementation during the luteal phase and in early pregnancy in the treatment of infertility: an educational bulletin. Fertil Steril 2008;89(4): 789-792

144. Hubayter ZR, Muasher SJ. Luteal supplementation in in vitro fertilization: more questions than answers. Fertil Steril 2008;89(4):749-758

145. Daya S, Gunby JL. WITHDRAWN: Luteal phase support in assisted reproduction cycles. Cochrane Database Syst Rev 2008;(3):CD004830

146. Keller DW, Wiest WG, Askin FB, Johnson LW, Strickler RC. Pseudocorpus luteum insufficiency: a local defect of progesterone action on endometrial stroma. J Clin Endocrinol Metab 1979;48(1):127-132

147. McRae MA, Blasco L, Lyttle CR. Serum hormones and their receptors in women with normal and inadequate corpus luteum function. Fertil Steril 1984;42(1):58-63

148. Abd-el-Maeboud KH, Eissa S, Kamel AS. Altered endometrial progesterone/oestrogen receptor ratio in luteal phase defect. Dis Markers 1997;13(2):107-116

149. Ilesanmi AO, Hawkins DA, Lessey BA. Immunohistochemical markers of uterine receptivity in the human endometrium. Microsc Res Tech 1993;25(3):208-222

150. Kliman HJ, Honig S, Walls D, Luna M, McSweet JC, Copperman AB. Optimization of endometrial preparation results in a normal endometrial function test (EFT) and good reproductive outcome in donor ovum recipients. J Assist Reprod Genet 2006;23(7-8):299-303

151. Wang B, Sheng JZ, He RH, Qian YL, Jin F, Huang HF. High expression of L-selectin ligand in secretory endometrium is associated with better endometrial receptivity and facilitates embryo implantation in human being. Am J Reprod Immunol 2008;60(2):127-134
152. Domínguez F, Remohí J, Pellicer A, Simón C. Human endometrial receptivity: a genomic approach. Reprod Biomed Online 2003;6(3):332-338

153. Horcajadas JA, Pellicer A, Simón C. Wide genomic analysis of human endometrial receptivity: new times, new opportunities. Hum Reprod Update 2007;13(1):77-86

154. Tapia A, Gangi LM, Zegers-Hochschild F, et al. Differences in the endometrial transcript profile during the receptive period between women who were refractory to implantation and those who achieved pregnancy. Hum Reprod 2008;23(2):340-351

155. Dey SK, Lim H, Das SK, et al. Molecular cues to implantation. Endocr Rev 2004;25(3):341-373

156. Donaghay M, Lessey BA. Uterine receptivity: alterations associated with benign gynecological disease. Semin Reprod Med 2007;25(6):461-475

157. de los Santos MJ, Mercader A, Galan A, et al. Implantation rates after two, three, or five days of embryo culture. Placenta 2003;24(Suppl B):13-19

158. Pope WF. Uterine asynchrony: a cause of embryonic loss. Biol Reprod 1988;39(5):999-1003

159. Achache H, Revel A. Endometrial receptivity markers, the journey to successful embryo implantation. Hum Reprod Update 2006;12(6):731-746

160. Aghajanova L, Hamilton AE, Giudice LC. Uterine receptivity to human embryonic implantation: histology, biomarkers, and transcriptomics. Semin Cell Dev Biol 2008; 19(2):204-211

161. Campbell KL, Rockett JC. Biomarkers of ovulation, endometrial receptivity, fertilisation, implantation and early pregnancy progression. Paediatr Perinat Epidemiol 2006; 20(Suppl 1):13-25

162. Cavagna M, Mantese JC. Biomarkers of endometrial receptivity-a review. Placenta 2003;24(Suppl B):3947

163. Haouzi D, Mahmoud K, Fourar M, et al. Identification of new biomarkers of human endometrial receptivity in the natural cycle. Hum Reprod 2009;24(1):198-205

164. Bell SC. Secretory endometrial/decidual proteins and their function in early pregnancy. J Reprod Fertil Suppl 1988;36: 109-125

165. Heffner LJ, Iddenden DA, Lyttle CR. Electrophoretic analyses of secreted human endometrial proteins: identification and characterization of luteal phase prolactin. J Clin Endocrinol Metab 1986;62(6):1288-1295

166. Santoro N, MacLaughlin DT, Bauer HH, Hargraves AA, Dichek HL, Richardson GS. In vitro protein production by the human endometrium. Biol Reprod 1989;40(5):10471055

167. Beier HM, Beier-Hellwig K, Sterzik S, et al. The significance of endometrial secretion proteins and their determination in human uterine secretions. In: Genazzani AR, Petraglia F, eds. Frontiers in Gynecologic and Obstetric Investigation. Carnforth, United Kingdom: Parthenon; 1993

168. Beier-Hellwig K, Bonn B, Sterzik K, et al. Uterine receptivity and endometrial secretory protein patterns. In: Dey SK, ed. Molecular and Cellular Aspects of Preiimplantation Processes. Vol 1. New York, NY: SpringerVerlag; 1995

169. Carson DD, Lagow E, Thathiah A, et al. Changes in gene expression during the early to mid-luteal (receptive phase) transition in human endometrium detected by high-density 
microarray screening. Mol Hum Reprod 2002;8(9):871879

170. Riesewijk A, Martín J, van Os R, et al. Gene expression profiling of human endometrial receptivity on days $\mathrm{LH}+2$ versus $\mathrm{LH}+7$ by microarray technology. Mol Hum Reprod 2003;9(5):253-264

171. Schmidt A, Groth P, Haendler B, et al. Gene expression during the implantation window: microarray analysis of human endometrial samples. Ernst Schering Res Found Workshop 2005;(52):139-157

172. Cowan BD, Hines RS, Brackin MN, Case ST. Temporal and cell-specific gene expression by human endometrium after coculture with trophoblast. Am J Obstet Gynecol 1999;180(4):806-814

173. Haendler B, Yamanouchi H, Lessey BA, Chwalisz K, Hess-Stumpp H. Cycle-dependent endometrial expression and hormonal regulation of the fibulin-1 gene. Mol Reprod Dev 2004;68(3):279-287

174. Tabibzadeh S, Sun XZ. Cytokine expression in human endometrium throughout the menstrual cycle. Hum Reprod 1992;7(9):1214-1221

175. Somkuti SG, Yuan L, Fritz MA, Lessey BA. Epidermal growth factor and sex steroids dynamically regulate a marker of endometrial receptivity in Ishikawa cells. J Clin Endocrinol Metab 1997;82(7):2192-2197

176. Daftary GS, Troy PJ, Bagot CN, Young SL, Taylor HS. Direct regulation of beta3-integrin subunit gene expression by HOXA10 in endometrial cells. Mol Endocrinol 2002; 16(3): 571-579

177. Apparao KB, Murray MJ, Fritz MA, et al. Osteopontin and its receptor alphavbeta(3) integrin are coexpressed in the human endometrium during the menstrual cycle but regulated differentially. J Clin Endocrinol Metab 2001;86(10):49915000

178. Genbacev OD, Prakobphol A, Foulk RA, et al. Trophoblast L-selectin-mediated adhesion at the maternal-fetal interface. Science 2003;299(5605):405-408

179. Lai TH, Zhao Y, Shih IeM, Ho CL, Bankowski B, Vlahos N. Expression of L-selectin ligands in human endometrium during the implantation window after controlled ovarian stimulation for oocyte donation. Fertil Steril 2006;85(3): 761-763
180. Foulk RA, Zdravkovic T, Genbacev O, Prakobphol A. Expression of L-selectin ligand MECA-79 as a predictive marker of human uterine receptivity. J Assist Reprod Genet 2007;24(7):316-321

181. Kumar S, Zhu LJ, Polihronis M, et al. Progesterone induces calcitonin gene expression in human endometrium within the putative window of implantation. J Clin Endocrinol Metab 1998;83(12):4443-4450

182. Zhu LJ, Cullinan-Bove K, Polihronis M, Bagchi MK, Bagchi IC. Calcitonin is a progesterone-regulated marker that forecasts the receptive state of endometrium during implantation. Endocrinology 1998;139(9):39233934

183. Li Q, Wang J, Armant DR, Bagchi MK, Bagchi IC. Calcitonin down-regulates $\mathrm{E}$-cadherin expression in rodent uterine epithelium during implantation. J Biol Chem 2002;277(48):46447-46455

184. Chen GTC, Getsios S, MacCalman CD. Cadherin-11 is a hormonally regulated cellular marker of decidualization in human endometrial stromal cells. Mol Reprod Dev 1999;52(2):158-165

185. MacCalman CD, Furth EE, Omigbodun A, Bronner M, Coutifaris C, Strauss JF III. Regulated expression of cadherin-11 in human epithelial cells: a role for cadherin-11 in trophoblast-endometrium interactions? Dev Dyn 1996; 206(2):201-211

186. Birdsall MA, Hopkisson JF, Grant KE, Barlow DH, Mardon HJ. Expression of heparin-binding epidermal growth factor messenger RNA in the human endometrium. Mol Hum Reprod 1996;2(1):31-34

187. Kimber SJ. Molecular interactions at the maternal-embryonic interface during the early phase of implantation. Semin Reprod Med 2000;18(3):237-253

188. Martin KL, Barlow DH, Sargent IL. Heparin-binding epidermal growth factor significantly improves human blastocyst development and hatching in serum-free medium. Hum Reprod 1998;13(6):1645-1652

189. Lessey BA, Gui Y, Apparao KB, Young SL, Mulholland J. Regulated expression of heparin-binding EGF-like growth factor (HB-EGF) in the human endometrium: a potential paracrine role during implantation. Mol Reprod Dev 2002; 62(4):446-455 